\title{
Support to the economic development of Vojvodina from Hungary
}

\author{
Подршка економском развоју Војводине из Мађарске \\ Ирен Габрић Молнар* \\ Универзитет у Новом Саду, Економски факултет у Суботици, Суботица \\ KovácsTeréz ${ }^{* *}$ \\ Scientific University of Pécs, Faculty of Philosophy, Institute of Social and Media Sciences, Hungary
}

\begin{abstract}
Abstract: In accordance with the provincial economic developmental program, the Hungarian community in Vojvodina assembled an economic developmental strategy in 2015, which not only coordinates with the objectives of the Serbian Government, but also with that of the Hungarian Government, to be specific to provide financial support to the region. The present study introduces how financial support was realized in the time period of 2016-2018. As a source for data collection, in-depth interviews were conducted and data provided by the Prosperitati Foundation, which coordinates the financial resources from Hungary, was also considered. The Prosperitati Foundation was in contact with the applicants/competitors, realized the process of evaluation, signed the contract, transferred the sum of financial support as well as oversaw the process of control. According to the basic idea of the program, only entrepreneurs with dual-citizenship (Serbian and Hungarian) could apply for the financial support, mostly farmers and small-sized entrepreneurs. In case of successful application, during the first period of the program, entrepreneurs could receive a maximum amount of 1 million RSD. The own share was $20 \%$, and pre-financing was established. Along the huge amount of interest, the output of the three years is more than 10.000 supported entrepreneurs/farmers, several hundred hectares of purchased land, several hundreds of rural houses and financial assistance of 250 million EUR. The main objective of the Hungarian Government was to support the middle and lower-middle class of Hungarians in Vojvodina. In the second phase of the program, along the small-sum subsidies large capital investments and technological developments were initiated for the purpose of establishing more workplaces.
\end{abstract}

Keywords: Prosperitati Foundation, small and medium-sized enterprises, farmers

Сажетак: У складу са Покрајинским програмом економског развоја, војвођански Мађари су 2015. године израдили стратегију економског развоја региона, која је испунила очекивања не само Владе Србије већ и Владе Мађарске. У раду смо приказали како је реализована финансијска подршка из Мађарске у периоду 2016-2018. Спровели смо дубинске интервјуе, а као извор података користили смо податке Фондације „Просперитати“, која координира мађарске грантове. Канцеларија „Просперитати“ расписала је конкурсе, прихватила пријаве, извршила бодовање, уговарање, доделу и контролу гранта. Суштина програма јесте да могу конкурисати сви они који живе у Војводини, двојни су држављани (Србије и Мађарске), по занимању су углавном пољопривредни произвођачи, власници малих компанија. У случају успешног тендера добили су највише милион динара новчане помоћи. Сопствени улог износио је $20 \%$, уз претфинансирање. Уз огромно интересовање грађана Србије за ову финансијску подршку, трогодишњи резултат је следећи: више од 10.000 финансираних субјеката, стотине хектара купљене земље и стотине

\footnotetext{
* gmolnariren@gmail.com

*** kovacs.terez@pte.hu
} 
купљених сеоских кућа, као и помоћ од 250 милиона евра. Мађарска влада је углавном помагала средњи и нижи средњи слој. У другој половини програма, осим малим преузећима, подршка ће бити упућена и великим инвестицијама ради технолошког развоја и стварања нових радних места.

Кључне речи: Фондација Просперитати, мали и средњи предузетници, пољопривредни произвођачи

\section{Introduction}

Following the Hungarian regime change of 1990, the external policy of the government began to show interest in the cultural lives of Hungarians living outside the border of Hungary. However, only in 2015 was a decision made to provide financial assistance for the purpose of economic development. ${ }^{1}$ It is important to highlight that the first considerable amount of economic and financial support was provided for the Hungarian community living in Vojvodina as they were the first to submit an adequate economic developmental strategy plan. The economic developmental supports were versatile: establishing new border crossing points, establishing financial networks as well as founding trade houses and banks. The following paper aims to discuss the financial support targeting small entrepreneurs and family businesses, who dispose of dual (Serbian and Hungarian) citizenship and have their permanent residence in Vojvodina.

For the compilation of the following paper, the present resources were consulted: (1) the documents and information published on the website of the Prosperitati Foundation, (2) personal participation in several residential forums where the application conditions were announced, (3) in-depth interview with one of the leaders of the program, (4) 14 semi-structured (anonymous) interviews with successful applicants. A limitation of the present paper is that it failed to interview any unsuccessful applicants.

Due to requirements of paper length, the present study does not discuss any theoretical background. However, the Nagy-Takács-Újhelyi's book, titled "The territorial and economic developmental strategy of Hungarian communities in Vojvodina" (further on Strategy) provides an in-depth overview of the document as well as the activities performed by the Prosperitati Foundation. From further on, the results of applications from 2016 to 2018 will be analyzed and the future of financial supports will also be considered.

\section{The territorial and economic developmental strategy of Hungarian communities in Vojvodina}

"The institutionalization of cross-border cooperation systems is evidently becoming necessary for the sake of more effective representation of interests, common measures

${ }^{1}$ The study was written in Hungarian and translated by Естера Габрић. 
and more effective arrangement of support programs. Among the non-institutional forms of cooperation, cultural and town-twinning relations as well as the cooperation of micro-regions and counties often draw on a common past. Among the institutional forms, the Euroregions have been the most effective forms of cross-border cooperation for areas that are geographically, historically, ecologically, ethnically and economically separated. In 2006, the European Union created an opportunity for its member states to establish European Grouping of Territorial Cooperation (EGTC) by the Regulation (EC) No 1082/2006. An EGTC as an acknowledged legal entity can support new approaches to cross-border governance, the legal framework of an EGTC can promote cross-border institutionalization, thus development of a multilevel government in the border areas.“ (Габрић Молнар, \& Soós 2016)

For the purpose of applying for international financial supports, a group of Hungarian economists in Vojvodina with the professional assistance of the representatives from other fields of science developed "The territorial and economic developmental strategy of Hungarian communities in Vojvodina" in 2015 . The editors of the publication were Imre Nagy PhD, Zoltán Takács PhD, \& Ákos Újhelyi M.Sc. as a representative of the Alliance of Vojvodina Hungarians. The above-mentioned strategy was submitted to the Hungarian government and accepted in a form of a resolution 1830/2015 (XI. 21). In 2016, in the first phase of the program, the Hungarian government decided to grant a total amount of 5 billion HUF, while in 2017 a total amount of 7.6 billion HUF in the form of non-refundable grants (18thMinistry of Foreign Affairs and Trade document). With regards to the large interest towards the grants and the success of the realized investments, the Hungarian Minister of Foreign Affairs announced in 2017 in Subotica that by the end of 2018, the Hungarian government would provide in total 30 billion HUF of further grants as well as 30 billion HUF of loans with preferential conditions with the purpose of the successful realization of the Strategy and the economic development of Vojvodina.

The document also highlights that among the residents of Vojvodina there is considerable entrepreneurial aptitude and in order to decrease the level of migration there is an immediate demand for establishing workplaces and increasing the competitiveness of enterprises. The Strategy targets such as - primarily - small and medium-sized enterprises that are not only capable of competing on the Serbian, but also on international markets, as well. Within the frames of infrastructural development, special emphasis is dedicated to transportation and logistics, the development of spreading business information and business relationship building services as well as the elimination of the borders' peripheral position (Nagy, \& Takács, Újhelyi 2015 - Strategy No. 7).

The Strategy elaborates upon the demographic issues and challenges of Vojvodina, along the low natality of the region, migration is continuous and largescale. In addition, our interview subjects also report the issue of unemployment: "If the 
circumstances and opportunities were provided for all those who left the country, many of them would return. If only there were more opportunities. They are apt and hardworking people and they would return; I believe the 80-90\% of them."

Separate chapter was dedicated to analysis of the agricultural sector in the Strategy. 1.646 million hectare of soil is arable in Vojvodina, out of which 1.577 million hectare is plough field. Soil is one of the most furthered ones in Europe. ${ }^{2}$ The agro-ecological conditions are optimal for economical production, i.e. adequate quality in adequate yield. The GDP contribution of agriculture is also excessive. In $2011,8 \%$ of agriculture, $41 \%$ of industry and construction industry and $51 \%$ of services constituted the GDP of Vojvodina. ${ }^{3}$

The Strategy's third chapter discusses the topic of economy. From the present paper's perspective, tourism and cross-border relations will be touched upon. Regarding tourism, mainly hotel capacities and the amendment of quality offer require development in Vojvodina.

As for the international subsidies of Serbia, the European Union offers various opportunities for receiving financial support. Vojvodina borders with several countries from the EU, to be specific Hungary, Croatia and Romania, thus in partnership with the above-mentioned countries the adequate regions of Vojvodina can apply for EU (INTERREG and IPA) funds. In addition to the financial support of the EU, the exchange of best practices and the establishment of new communicational relationships along the border are also very beneficial for Vojvodina. Several studies have discussed the positive experiences of Vojvodina. See Literature: Ricz, András (2017); Ricz, András \& Gábrity Molnár, Irén (2010); Ricz, \& András (2011); Ricz, András \& Nagy, Imre (2014); Имре Нађ, Андраш Риц, Ђула Рибар, \& Миклош Нађ (2015); Nagy Imre, Ricz András \& Nagy Miklós (2015).

\section{Implementation of the applications procedure}

The reception of the Hungarian financial subsidy and the actual implementation of the applications in Vojvodina are realized by the Prosperitati Foundation in Subotica. The organizational structure of the Foundation consists of the Directory, which announces as well as evaluates the applications, and 9 territorial offices that provide assistance in implementation. In Bačka, there are 7, while in Banat, there are 2 territorial offices (Graph 1). Their location is in accordance with the territorial distribution of Hungarians

\footnotetext{
${ }^{2}$ The demand for plough fields is high. Their prices are between 17-20,000 EUR/hectare in Bačka.

${ }^{3}$ In Serbia, agriculture composes the $20-23 \%$ of total gross output. If we include the processing industry as well, the annual output is $40-43 \%$. Serbia's export of agricultural products is $23-25 \%$. The GDP's $11,9 \%$ is agriculture, forestry and fishery, while $3.3 \%$ is food processing. The largest amount is produced as well as exported from: corn, wheat, comb flower, beet, soy, potato, apple, plum, grape, pork, beef, poultry and milk.
} 
living in Vojvodina: primarily along the river Tisa and North Bačka, in the agglomeration of Subotica. 2 fellow workers are employed at the territorial offices, except for the office in Subotica, which bears a central role in the process of application, thus more fellow workers are employed. The idea was that the applicants would not need to hire professional project writers, therefore the offices were equipped with adequate IT appliances, while one of the main roles of the fellow workers is to provide adequate information to the applicants. All the required information are also available online, but prior to that, in January 2016 the Alliance of Hungarians in Vojvodina held several residential forums throughout Vojvodina to inform the public upon the financial subsidy and its objectives of the Hungarian government.

Graph 1.: The territorial distribution of the Prosperitati offices on the territory of Vojvodina

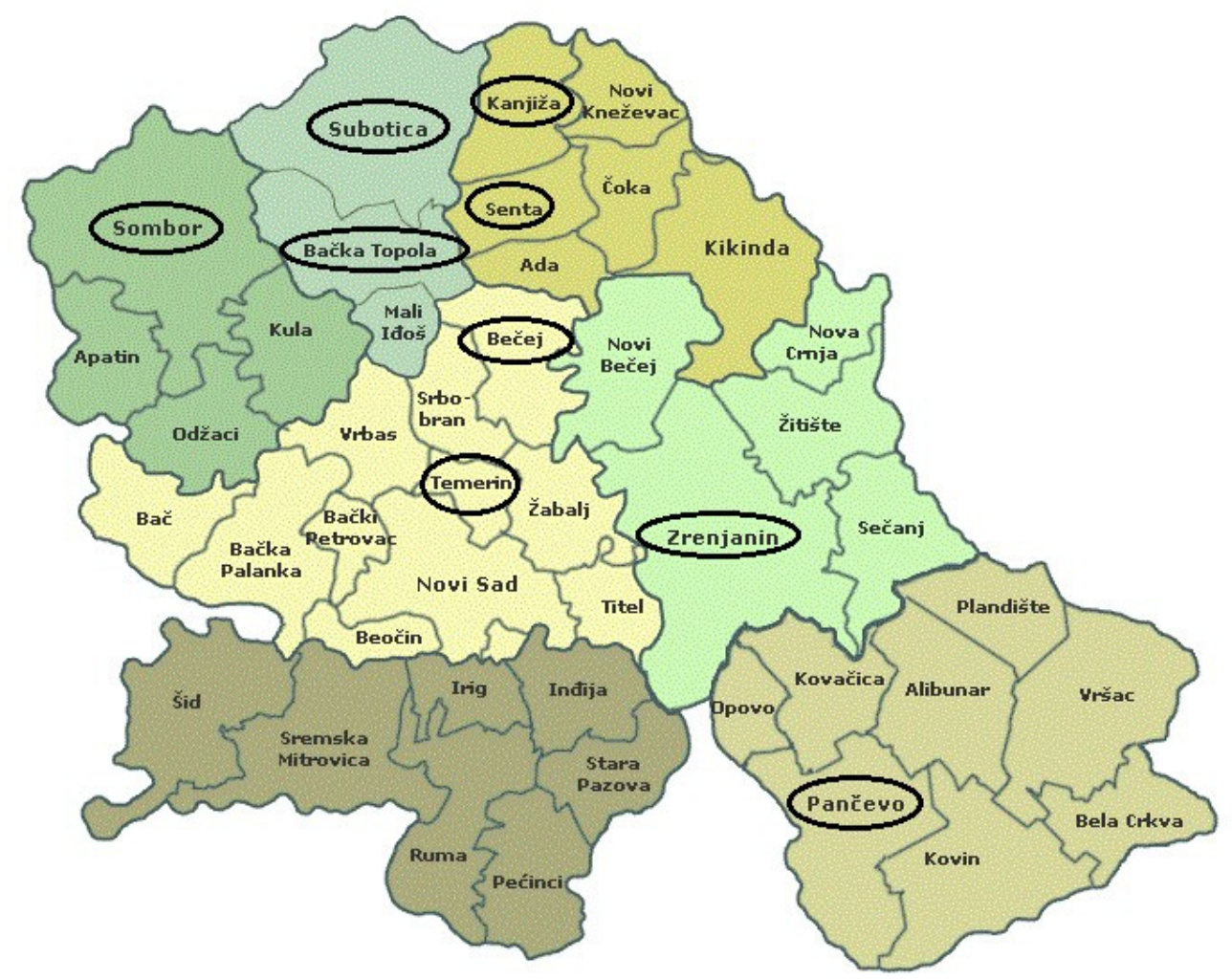

Source: own editing based on the information provided by www.prosperitati.rs

Residential forums were continuous during the further phases of applications. There were a lot of inquirers at the first forum and people were interested in the possible opportunities. The Prosperitati Foundation also launched an electronic newsletter. The daily newspaper, Magyar Szó (Hungarian Word), but other 
representatives of the press (even Serbian) provided continuous coverage about the application. The organized method of information flow contributed to the successes of the program. Namely, one of the winning applicant's answer when he was asked where he learned about the subsidy opportunity was:"...from everywhere, well, those who have not heard of the program must sit in a very dark room."

The entitlement and process of application is regulated by the General Regulations of the Prosperitati Foundation (from further on the Regulation) and the possible circle of applicants. Whoever is entitled to apply for the subsidy, the following regulation can be read: "Natural persons who dispose of citizenships of the Republic of Serbia and the Republic of Hungary as well as dispose of residential address registered on the territory of the Autonomous Province of Vojvodina are entitled to application. Respectively, legal entities whose seat is registered on the territory of the Autonomous Province of Vojvodina and their founders and/or the majority of their employees are natural persons who dispose of citizenships of The Republic of Serbia and The Republic of Hungary as well as dispose of residential address registered on the territory of the Autonomous Province of Vojvodina." (www.prosperitati.rs/sites/) The latter means that not only enterprises of Hungarian ownership, but also enterprises of Serbian or other nationalities can also apply for the subsidy if the majority of their employees (for instance 70\%) dispose of dual (Serbian and Hungarian) citizenship. The degree of the financial support cannot exceed $80 \%$ of the total project budget and the margin is minimum $20 \%$ which has to be ensured by the applicant. The latter sum coincides with the VAT percentage in Serbia that goes into the Serbian national budget. The applicant, before submitting their application, is required to contact the supplier/seller from whom the applicant aims to purchase the machine, animal or plantation in order to provide a pro-forma invoice. The applications need to be submitted at the territorial offices accompanied by the company's/applicant's business plan in Hungarian, but the certificates of authorities (such as bank, police department, municipality) as well as the pro-forma invoice are in Serbian, and are not expected to be translated.

The Directory of the Foundation - based on the principles of the Regulations and the professional committee evaluate the applications, judge them by points and also rank them maximum 45 days following the submission deadline. Hereon, the ranking is forwarded to the decision making Committee appointed by the Hungarian Ministry of Foreign Affairs and Trade in order to announce their final decisions. Thus, the final decision is made by Budapest, but it is based on the recommendations of the Directory. The notification of the applicants and contract signing is also realized by the Prosperitati Foundation.

The subsidy applications are transparent: official publication on the Prosperitati website (www.prosperitati.rs/palyazati-eredmenyek), which also publishes the name of the winning applicant, their place of residence (in certain cases even their residential address), the number of points they have achieved and the amount of financial support. 
The applicants who did not receive a positive evaluation can also be found on the website. According to the justification of the Foundation, they are either not entitled to apply for the subsidy or their applications failed to meet the formal requirements. Based on the reports of our interviewees, the majority of the applicants wrote their applications independently and compiled their business plans with the assistance of a friend. The number of those who hired a professional project writer was low. Those who failed to receive a positive evaluation reported that they should have hired a professional project writer to help them write and compile the required documents.

At the beginning of project implementation, the successful applicant is required to deposit the $20 \%$ own share on the bank account of the supplier/seller that was indicated in the application form. Following the confirmation of the deposit, the Prosperitati Foundation transfers the remaining $80 \%$ to the supplier's/seller's bank account. Hereon, the applicant is allowed to take over the required product.

\section{The character of the subsidy}

Application started at the beginning of the 2016. There have been 6 cycles of application so far. The aims and subjects were clearly defined regarding each application cycle. The subsidy applied for - with two exceptions - did not exceed 1 million $\mathrm{RSD}^{4}$. Exception was made in case of purchasing country houses and landmass, at the former the maximum amount of subsidy was 1.2 million, while at the latter 2 million RSD. Each applicant could apply for only one subject, however, within that applicants could require more than one equipment and could also re-apply in the future for further subsidy. There were two application subjects that were announced in three application cycles, namely subsidy of agricultural character and the purchase of appliances for micro and small enterprises.

The chronological order of application results:

2016/1cycle of application: I-01 (expansion of sources), K-01, M-02, M-04, M05 (expansion of sources), Successful application in depending on the resource (I1, K1, M2, M4, M5), I01 - House purchase, M01 - Polytunnel, M02 -Breeding animals and bees, M03 - Ice-fender nets, M04 - Agricultural machines and related appliances, M05 - Irrigation system, M06 - Polycarpicplantation, K01 - Appliances for sole proprietorships, micro and small enterprises, K02 - Standards and licenses, K03 Tourism.

2016/2cycle of application: K05 - Startup, K06 - Subsidy for interests, M07 Investment for the production of items with and added value, M08 - Purchase of agricultural landmass, K04 - NGO

${ }^{4}$ Exchange rate (approximately): 1 EUR=120 RSD, $100 \mathrm{HUF}=40 \mathrm{RSD}, 100 \mathrm{RSD}=250 \mathrm{HUF}$ 
2016/3cycle of application: K-01, M-06, M-04

2017/1cycle of application: H-02/2017-1, H-01/2017-1-The combined support of economic developments with an emphasized importance

2017/2cycle of application M-08-2017-2 - Purchase of agricultural landmass, H03-2017-2-Agricultural and economic developments, I-01/2017-2 - House purchase

2018/1 cycle of application: K05 -Startup enterprises, MI-04-G-2018-1Crop, MI-04-GY-2018-1Fruit, MI-04-Z-2018-1Vegetable, MI-04-S-2018-1Swine, MI-04-M2018-1Honey, MK-07-2018-1Local products, K-08-2018-1Corner of products, K05 Startup, K05 - Startup

\section{8/2cycle of application: I-01/2018-2 - House purchase}

As it turned out during residential forums, the purchase of agricultural machines was the highest demand which was also proved by the subject and number of applications. By looking at the list of successful applications, it can be concluded that there were not many agricultural applications that reached that maximum amount of subsidy. The majority of applicants were cautious and applied for smaller amounts of subsidy so that the own share would be also small. Second-hand machines were also among the purchasable appliances, however they had to be provided from a domestic seller. Unfortunately, it has also occurred that the seller - before the enclosing of the purchase sold the item to another buyer. Such applications fell through and the applicant had to re-apply for the subsidy and look for another appliance. In case of agricultural appliances, applications for laying plantation as well as the purchase office-fender net, polytunnel, irrigation system, breeding animals and bees were also accepted.

Based on the data gathered from the interview, the majority of agricultural applicants' were also farmers. The applicants themselves disposed of a school-leaving exam from a grammar school or secondary vocational school or started their tertiary education, however did not complete it. The majority of applicants above the age of 30 had a state job for several years, but - as the interviewees revealed - due to the layoffs of state jobs and their poor economic situation decided to return to their parents' farmland. Applicants under the age of 30 were excited to launch the cultivation of unique plants, such as strawberry or hazelnut plantations. They usually applied for cold stores or laying of plantation or else hazelnut crusher machine in the second cycle of application. Newer and newer ideas were born within every enterprise, for instance cheese factory and production of syrup. A 26-year-old applicant, who is also mother of two, imagined her future as follows: "As we discussed with my husband, when our children grow up, we would like to have an enterprise of three branches, so that they could inherit it as we did from our parents. To have at least something to start their lives with".

Micro and small enterprises applied mostly for the purchase of appliances. By looking at the list of successful applications, the owners of micro and small enterprises were braver and dared to risk in comparison to the agricultural applicants. Several en- 
trepreneurs applied for the maximum amount of subsidy. For instance, a family business (where the parents co-work with their 24-year-old son) engaged in selling paper and books applied for the purchase of a small van. Another family business (engaging the siblings, their parents and three more employees), which produces wooden toys for the development of disabled children, applied for the purchase of a three dimensional $\mathrm{CNC}$ machines and the establishment of another workplace. The owner of a leather goods production company requested the purchase of a specific sewing machine, while a confectioner applied for a refrigerator and baking machine. Micro and small enterprises could also request subsidy for the establishment of tourist accommodation, their expansion or their standardization.

The program also enabled the application of startup enterprises, as well. Even within professional circles, the concept of startup has been known only for 6-7 years. Definitions determining the concept usually evolve around the following notions: small capital, knowledge and rapid expansion. "...those ideas that are based on startups are solutions for a problem that significantly hinder the growing opportunities of an enterprise. Startups have a higher chance of on the international market, if they are global and the problem-resolution affects more companies." (Kővágó 2015: 44.) Application consisted of 2 components: potential applicants had to participate in a 40-hour course and based on their business plan they could apply for the purchase of basic appliances. In this case, no own contribution was demanded. However, it was an important condition that applicants - until the submission of their application - were below the age of 40. Applicants were young adults with innovative ideas, for instance one of them applies for IT appliances that precisely assessed when grapes require spraying in order to avoid redundant spraying. This is not only beneficial for oenologists, but also for the environment.

The purchase of countryside houses is an important step for young married couples who have not owned any real estate before and at least one of them was under the age of 45 before the submission of their application. The maximum amount of subsidy that applicants could request was 1.2 million RSD. The maximum price of the desired real estate could not exceed 2 million RSD. A couple of civil partnership who have a children and has been living in sublet apartment for more than 10 years, successfully applied for subsidy declared the following during an interview: "When we move in our own home, we will start planning on having another child. "However, there were disappointments, too: one couple was informed that their application fell through, so then they purchase another, but smaller house. A month later, they were informed upon their successful application, however could not purchase the original real estate they opted for. 


\section{The efficiency of the subsidy}

Throughout the last three years in Vojvodina, developments of 250 million EUR were realized with the financial support of Hungary, 23 factories were built and more than 10.000 applications were accepted. Just a reminder: in 2016, throughout the first two application cycles there were almost 3.000 applications, out of which $81 \%$ was financed. It can be concluded from the interviews conducted among successful applicants that throughout the last 3 years, the income of applicants rose with $25 \%$ on average and they could raise the number of their employees with $30 \%{ }^{5}$

"More than 11.000 applications were submitted and currently there are 10.139 successful applications, and by 2018 - based on predictions - there will be 300 further applications" - said the manager of the Prosperitati Foundation, adding that the $40 \%$ of the 250 million EUR of investment is subsidy, $60 \%$ is own contribution or credit. ${ }^{6}$ Various fields of the industry were developed as we have a new construction material factory, chain factory, bicycle factory and the industry of automobiles and bag production. The financial support from Hungary reached more than 150 municipalities in Vojvodina. There were 600 winners for the purchase of country houses, more than 560 hectares of landmass was also supported.

One RSD of investment resulted in at least one RSD of another investment. Due to medium and large developments, 1.400 workplaces were established and 4.500 family businesses were integrated into the processing industry. The office manager of the Prosperitati Foundation announced that throughout 2019 new economic developmental cycle will be announced. According to the plans, in addition to touristic developments, the so far most successful applications will also be opened, i.e. purchase of landmass and country houses as well as the support of micro and small enterprises.

The interview subjects were successful applicants and each of them declared that the subsidy meant a lot for them: "It opened up a new dimension, there is an obvious development, because - so far - we financed everything from own contribution"; "I have not received anything in my life so far and this is a big event, the crown of my work"; "It provided a possibility for people to grasp into something and that there is future here". Successful application also raises the willingness to launch enterprises. In addition, successful applications have an encouraging influence especially if videos of applicants were published on the Prosperitati website.

The Serbian state is also benefiting from the Hungarian subsidy as new enterprises and investments launch in the region. In case of each purchase the $20 \%$

\footnotetext{
${ }^{5}$ https://www.prosperitati.rs/gazdasagfejlesztesi-program-pozitiv-hatasat-mara-tobb-tizezer-polgarmegerezte $(23 / 01 / 2019)$.

${ }^{6}$ https://www.prosperitati.rs/juhasz-balint-visszaigazolasra-kerult-hogy-gazdasagfejlesztesistrategianak-van-hatasa-es-ertelme (20/01/2019).
} 
VAT remains in the state budget. The successful applicant becomes a better tax-paying resident. Subsidies not only support the applicants' enterprise or their families, but also expand the number of employees and refresh the market of subcontractors. (Kovács 2017). The subsidy of the Hungarian government directly supports Hungarian residents who dispose of Serbian-Hungarian citizenship in Vojvodina, but their purchases and sales indirectly influences sellers, service providers and banks in the region. In the long run, the subsidy has a positive impact on the Serbian economic life.

\section{Conclusion}

The Hungarian economic developmental subsidy on the territory of Vojvodina managed by the Prosperitati Foundation has a positive impact on the bilateral relationship of both neighboring countries. Due to the openness of the Serbian government no obstacles were met during program implementation. Throughout the three years, 23 large, further 166 medium-sized and more than 10.000 small-sized developments were realized. The purchase of 600 country houses were supported, there were 220 projects of landmass purchase (560 hectare). It is important to note that the appliance and standard purchase of 1.080 micro, small enterprises and family businesses were supported, there were 56 touristic projects, nearly 8.000 small amount of agricultural subsidy and 344 startup businesses.

The strategic objective of the Hungarian government is to support the Hungarian population in Vojvodina to ensure that they make their ways in Serbia with financial and economic support. In addition, the subsidy has a positive impact on the stability and economic development of the entire region. In the future cycle of the program, the realization of not only further small-scale, but also 6 large-scale investments (www.vajma.info/cikk/vajdasag) that generate further economic development in the region, resulting in positive bilateral relationships between the two countries and their residents.

\section{References}

Габрић Молнар, И., \& Soós, Е. (2016). The instruments of the European Union crossborder regional cooperation. Анали Економског факултета у Суботиџи, 52(36), 3 24.

Kővágó, G. (2015). Tudásintenziv üzleti szolgáltatások marketinginnovációs eszközeinek vizsgálata a mikro- és kisvállalkozási szektorban. Докторска дисертација. Шопрон, Мађарска.

Kovács, T. (2017). A Vajdasági Magyar Közösségek Terület- és Gazdaságfejlesztési Stratégiájának megvalósítási tapasztalatai. Gazdálkodás, 62(1), 49-61. 
Nagy, I., Takács, Z., \& Újhelyi Á. (2015): A vajdasági Magyar közösségek terület- és gazdaságfejlesztési stratégiájának. Суботица: Vajdasági Magyar Szövetség/Савез војвођанских Мађара.

Ricz, A. (2017). A határon átívelö programok hatásai Vajdaság területi fejlödésére, Доктороска дисертација. Ђep: Széchenyi István Egyetem Regionálisés Gazdaságtudományi Doktori Iskola.

Ricz, A, \& Gábrity Molnár, I. (2010). A Vajdaság régiókapcsolatai a Dél-Alfölddel. Soós, E. \& Fejes, Z. (ур.). Régió a hármashatármentén, Dél-Alföldi Régió, Сегедин: Szegedi Tudományegyetem, Állami- és Jogtudományi Kar, Politológiai Tanszék.

Ricz, A. (2011). A határon átívelő Európai uniós programok hatásai a vajdasági magyarság helyzetére. Gábrity Molnár, I. (yp.), Magyarságkutatás Vajdaságban, Суботица: Magyarságkutató Tudományos Társaság.

Ricz, A. \& Nagy, I. (2014). Határon átívelő programok területi dimenziói Vajdaságban. Ricz, A., \& Takács, Z. (ур.), Regionális kaleidoszkóp, Суботица: Regionális Tudományi Társaság

Нађ, И., Риц, А., Рибар, Ђ., \& Нађ, М. (2015). Спремност и припремљеност локалних самоуправа АП Војводине за пријем и коришћење развојних фондова Европске Уније. Темерин: Просперо

Nagy, I., Ricz, A., \& Nagy, M. (2015). Az INTERREG IIIA-CARDS (CBC) támogatások földrajzi sajátosságai és hatásai a helyi és területi fejlödésre a Vajdaság AT határrégióiban. Ricz, A., \& Takács, Z. (ур.). A régió TÍZpróbája, Суботица: Regionális Tudományi Társaság.

$18^{\text {th }}$ Ministry of Foreign Affairs and Trade: http://www.parlament.hu/irom40/10377/adatok/fejezetek/18.pdf (12/07/2017). https://www.prosperitati.rs/gazdasagfejlesztesi-program-pozitiv-hatasat-mara-tobbtizezer-polgar-megerezte (23/01/2019).

https://www.prosperitati.rs/juhasz-balint-visszaigazolasra-kerult-hogygazdasagfejlesztesi-strategianak-van-hatasa-es-ertelme (20/01/2019).

http://www.prosperitati.rs/sites/default/files/altalanos_szabalyzat_20161114.pdf (16/07/2017).

http://www.prosperitati.rs/palyazati-eredmenyek (12/01/2019).

http://www.prosperitati.rs/unnepelyes-szerzodesalairas-prosperitati-alapitvany-3palyazati-korenek-nyerteseivel (30/07/2017).

http://www.prosperitati.rs/prosperitati-2017-aprilis-13-video (01/08/2017). 
http://www.vajma.info/cikk/vajdasag/21627/Hat-nagylepteku-mezogazdasagifejlesztest-tamogat-a- (23/07/2017).

\section{Summary}

The support of the Hungarian government regarding the economic development of Vojvodina has become very noticeable since 2016. The procedure for applying and implementing financial assistance is conducted by the Prosperitati Foundation in Subotica. Investments positively affect the bilateral relations of the two neighboring countries. The openness of the Government of Serbia is shown by the fact that the implementation of the program has been positively welcome. During the three years, 23 major development activities were carried out, and 166 medium-size and over 10.000 small-size enterprises were financially supported. Within the project, 600 countryside houses were purchased, there were 220 land purchases (in total 560 hectares). The activation and standardization of 1.080 micro, small and family enterprises in Vojvodina, followed by 56 tourism projects were also realized. Almost 8.000 small farms and 344 start-ups received financial support as well.

The Hungarian government's strategic goal is that Hungarians living in Vojvodina remain in their home country, in Serbia and contribute to economic development. Investments have a positive impact on the social stability of the region. The Hungarian government was mainly assisted by the middle and lower middle classes in Vojvodina. In continuation of the support program for our regions from the neighboring country, they foresee not only subsidies to small enterprises, but also bigger investments are also planned that will contribute to the opening of new workplaces in Serbia, as well as to the increase of economic exchange between the two countries. 